\title{
KEGIATAN KEWIRAUSAHAAN SEBAGAI SUMBER BELAJAR IPS
}

(Studi Kasus Cappucino Cincau Abude Jl. Cempaka IX, Mawar, Kota Banjarmasin)

\author{
Mastiah \\ Mahasiswa Program Studi Pendidikan Ilmu Pengetahuan Sosial (IPS) \\ FKIP Universitas Lambung Mangkurat Banjarmasin \\ Email : mastiahasti934@gmail.com
}

\begin{abstract}
Entrepreneurship can run if there is a strong will and determination possessed by each individual. One form of business that I will discuss in this research is the cappunico cincau franchise which is growing very rapidly. Why am I interested in researching this, namely because the turnover they get is tens or even hundreds of millions per month. Of course, this research can also be used as a source of social studies learning, which is related to economics. This is also in the environment around students, so that it will make it easier for them to understand learning. Thus a quality social studies learning is created by linking various activities in the students' environment.
\end{abstract}

Keywords : Entrepreneurship, Franchise, Social Studies Learning Resources

\begin{abstract}
ABSTRAK
Kewirausahaan dapat berjalan jika ada niat dan tekad yang kuat dimiliki oleh setiap individu. Salah satu bentuk usaha yang akan saya bahas dalam penelitian ini yaitu franchise cappunico cincau yang berkembang sangat pesat. Mengapa saya tertetarik meneliti tentang ini, yaitu karena omset yang mereka dapatkan puluhan bahkan sampai ratusan juta perbulannya. Penelitian ini juga tentunya dapat dijadikan sebagai sumber belajar IPS yang dimana di dalamnya terkait dengan ilmu ekonomi. Hal ini juga berada dilingkungan sekitar peserta didik, sehingga akan memudahkan mereka dalam memahami pembelajaran. Dengan demikian terciptalah pembelajaraan IPS yang berkualitas dengan mengaitkan berbagai kegiatan yang berada dilingkungan sekitar para peserta didik.
\end{abstract}

Kata Kunci : Kewirausahaan, Franchise, Sumber Belajar IPS

\section{PENDAHULUAN}

Usaha waralaba awal mula dikenal di Eropa dan usaha ini sudah lama berkembang disana dengan nama Franchise. Kata Franchise itu sendiri berasal dari bahasa Perancis yang berarti bebas dari hambatan (free from servitude). Sehingga dalam bidang bisnis franchise berarti kebebasan bagi setiap individu atau wirausahawan untuk menjalankan usaha di berbagai wilayah tertentu. Menurut pasal 1 angka 1 Peraturan Pemerintah RI No.42 tahun 2007 tentang waralaba. Waralaba merupakan hak individu maupun badan usaha terhadap sistem bisnis dengan ciri khas tersendiri yaitu memasarkan barang atau jasa yang dapat dimanfaatkan dan digunakan oleh pihak lain berdasarakan perjanjian waralaba itu sendiri. (Firdawaty, L, 2011). 
Indonesia mulai mengenal sistem waralaba pada tahun 1950-an, yang dimana dimulai dengan bermunculan berbagai dealer kendaraan bermotor melalui pembelian lisensi. Selanjutnya perkembangan kedua pada tahun 1970-an yang dimulai dengan lisensi plus, yang dimana franchise tidak hanya menjadi penyalur barang atau jasa tetapi juga mampu memproduksi suatu produk. (Andini, D. P, 2013).

Peluang usaha franchise ini sangat terbuka lebar di negara Indonesia, begitu pula sektornya yang meliputi berbagai bidang. Pelaku usaha waralaba ini sendiri memiliki prospek yang sangat cerah untuk mengembangkan ide usaha yang ia miliki. Jika inovasi yang diberikan oleh pelaku usaha banyak menarik minat para masyarakat Indonesia yang komsumtif maka tidak dapat dipungkiri bahwa keuntungan yang cukup besar akan didapatkan dalam kurun waktu yang singkat. (Pamungkas, R. \& Magnadi, R. H, 2014).

Usaha Capcin Abude yang saya teliti kali ini merupakan salah satu franchise yang memiliki cabang utama di Banjarmasin. Sejak usaha ini berdiri pada tahun 2014 hingga sekarang banyak mengalami peningkatan. Pada awal merintis franchise ini hanya berpendapatan ratusan ribu perbulan, namun pada saat ini pengghasilnya meningkat hingga puluhan juta perbulan. Dalam laporan ini akan dibahas lebih lanjut terkait dengan strategi usaha yang mereka dilakukan, sehingga capcin Abude mencapai kesuksesan hingga saat ini.

\section{PEMBAHASAN}

Masyarakat kebanyakan berpendapat bahwa kewirausahaan erat kaitannya dengan praktik langsung kerja dan hanya dapat dilakukan oleh orang-orang tertentu. Namun pendapat ini dinilai kurang tepat, karena jiwa kewirausahan mampu dimiliki oleh setiap orang yang mempu dalam mengembangkan kemampuan berpikir kreaktif dan inovatif. Dalam dunia kewirausahaan seseorang harus mampu memanfaatkan berbagai peluang yang ada dan jika sudah ada peluang yang tepat maka hanya perlu ditambahkan ide yang kreatif dan inovatif.

Kewirausahaan sendiri didefinisikan sebagai kemampuan dalam berpikir berkreasi dan berpikir kreatif dalam memanfaatkan peluang yang ada untuk mencapai suatu kesuksesan. Proses berpikir kreatif sendiri dimulai dari munculnya ide yang dikembangkan menjadi sebuah inovasi yang berbeda dari orang lain dan dapat menarik minat banyak masyarakat untuk mencoba produk tersebut. Tentunya untuk mencapai semua ini perlu adanya peninjauan lapangan terlebih dahulu untuk menyesuaikan apa yang dibutuhkan pasar saat ini. (Sunawiri, B, \& Iqbal, M, 2018). 
Kewirausahaan merupakan disiplin ilmu yang mempelajari tentang nilai kemampuan yang dimiliki oleh sesorang dalam menghadapi berbagai persoalan dan tantangan hidup yang dihadapi untuk memperoleh peluang usaha dari berbagai resiko yang dihadapi. Menurut Thomas W, Zimmer mendefinisikan bahwa pemikiran kreatif, ketekunan, kedisiplinan serta mampu memahami peluang pasar. (Sunarya, P., \& Saefullah, A, 2011).

Pendidikan IPS merupakan ilmu pengatahuan yang terintegrasi dari beberapa disiplin ilmu dan di dalamnya juga terdapat bebagai konsep dari disiplin ilmu sosial humaniora, sains, maupun berbagai isu sosial yang ada di kehidupan masyarakat. Dalam pembelajaran IPS sendiri sumber belajar dapat diambil dari berbagai hal, salah satunya yaitu yang ada di lingkungan sekitar peserta didik. Banyak sekali yang dapat dijadikan sumber belajar. Penelitian yang penulis ambil disini juga dapat dikaitkan sebagai sumber belajar dalam ilmu ekonomi. Ilmu ekonomi merupakan disiplin ilmu yang terintegrasi dalam rumpun IPS sendiri. Maka dari itu kegiatan kewirausahaan yang akan saya bahas selanjutkan dapat dikaitkan dalam pembelajaran IPS. (ABBAS, E. W, Hidayat Purta, M. A., \& Noor Handy, M. R., 2019).

Pada penelitan ini penulis meneliti mengenai salah satu franchise yang adan di Kota Banjarmasin, Kalimantan Selatan. Usaha yang di angkat disini ialah minuman Cappucino Cincau dengan Brand Abude. Mengapa penulis tertarik dengan franchise ini, karena dengan usaha jajanan seperti itu bisa memperoleh penghasilan puluhan bahkan mencapai ratusan juta perbulannya. Terkait strategi apa yang mereka gunakan dalam pemasarannya akan dibahas lebih lanjut oleh penulis, melalui wawancara langsung kepada owner usaha ini.

Cappocino Cincau atau yang sering disebut capcin merupakan salah satu jajanan minuman yang ada di Indonesia. Cappocino juga merupakan minuman yang banyak menarik minat para konsumen sejak tahun 2013. Pada awal munculnya minuman ini banyak mansyarakat yang rela berjam-jam hanya untuk mendapatkan minuman tersebut. Kekhasan rasa es cappuccino yang di padukan dengan potongan cincau seolah menjadi perpaduan yang menarik dan membuat penasaran banyak konsumen. Minuman ini diminati oleh berbagai kalangan baik anak-anak, remaja maupun orang dewasa. Dalam minuman cappuccino ini juga terdapat kandungan kafein ringan yang menyegarkan dan cincau yang mengadung banyak manfaat bagi kesehatan tubuh manusia, sehingga tidak heran jika minuman ini banyak diminati oleh masyarakat.

Saya melakukan wawancara pada pemimpin Capcin Abude, yaitu :

Nama

: Budi Permana, S.E 
TTL : Banjarmasin, 29 Mei 1992

Alamat : Jl. Sultan Adam, Gang Nusa Indah, No. 52

Nama Abude sendiri di diambil dari tiga nama yaitu Alfi, Ahmad Hasan dan Budi Permana. Mereka bertiga juga sering kerepotan saat melayani banyak pelanggan dan pusing saat ada bahan baku yang habis tapi pelanggan terus berdatangan sehingga mereka tidak bisa meluangkan waktu untuk segera pergi membeli bahan baku. Maka hal demikian dalam istilah bahasa banjar disebut "Abut". Akhirnya dari sana mereka memberikan Brend usaha es cappuccino ini dengan nama Abude.

Budi Permana atau biasa dipanggil Ka Budi merupakan pemimpin dari Abude Grup. Pada saat wawancara beliau menjelaskan bahwa awalnya Abude Grup di bentuk pada tahun 2014. Sebelum pembentukan usaha capcin Abude ini beliau bersama tim merintis usaha gorengan yaitu tahu dan jamur krispy. Kemudian di depan outlet beliau ada seorang pedagang pendatang dari Pulau Jawa, pedagang itulah yang pertama kali berjualan minuman es cappocino cincau ini. Melihat usaha pedangang itu berpotensi bagus dan banyak menarik minat banyak pelanggan, akhirnya beliau penasaran akan rasa dari capcin tersebut lalu ia membeli dan mencobanya. Awal pertama mencoba ia langsung terkesan karena rasanya yang enak dan harganya terjangkau hanya Rp. 5000. Dengan harga yang murah dan rasa yang enak maka menjadi hal yang worth it bagi masyarakat untuk membeli minuman tersebut. Sehingga pada waktu itu beliau langsung mengajak pedangang tersebut untuk kerjasama, namun ternyata pedagang tersebut tidak bersedia, karena usaha yang di jalaninya merupakan usaha yang dirintis bersama keluarga maka ia tidak mau melibatkan orang luar dalam menjalankannya.

Kemudian beliau bersama tim mencari ide untuk membuka usaha capcin sendiri tanpa bekerjasama dengan pedangang capcin sebelumnya. Beliau bersama tim berdiskusi bagaimana cara menginovasikan es cappuccino cincau dengan harga yang sama namun kualitas lebih baik. Untuk bisa mendapatkan kualitas yang lebih baik maka mereka mulai mencoba rasa minuman di cafe, di warung-warung kopi, dan mencoba minuman sejenis kopi di beberapa mall. Akhirnya perjungan mereka membuahkan hasil dengan menemukan rasa yang khas dari beberapa tempat tersebut, sehingga mereka yakin untuk membuka usaha yang sama tapi dengan rasa dan kualitas yang lebih baik. Ide dan inspirasi usaha ini mereka dapatkan dari luar namun mereka inovasikan dari segi rasa.

Sejak saat itu mereka memutuskan untuk menghentikan usaha gorengan sebelumnya dan membuka usaha es cappuccino cincau ini dari hasil penjualan peralatan sebelumnya. Modal 
awal mereka untuk membuka usaha ini yaitu Rp.3000.000,. Uang tersebut kemudian direalisasikan untuk membeli gerobak bekas dan berbagai alat untuk keperluan pembuatan capcin, kemudian uang yang tersisa untuk membeli bahan baku yaitu Rp. 200.000,. Uang inilah yang selalu di putar tiap hari, jika penjualan capcin siang habis maka malamnya mereka pergi membeli bahan baku untuk hari berikutnya. Satu sampai dua bulan pertama masih berjalan demikian sampai modal memang benar-benar terkumpul, setelah itu barulah mereka bisa lebih bernafas lega karena bisa menyetok bahan baku dan pembeliannya hanya dilakukan seminggu sekali.

Budi Permana menuturkan bahwa minuman yang ia jual harus memberikan kesan tersendiri bagi para konsumennya. Kesan tersebut dimunculkan dari rasa minuman yang ia jual, jika sudah demikian maka akan secara otomatis bisa menarik pelanggan datang kembali untuk membeli. Selain dari rasa harga yang ditawarkanpun juga terjangkau. Beliau menuturkan jika ingin mempertahankan keunggulan suatu produk maka ia harus mampu menyesuaikan dengan kondisi pasar, memilih lokasi yang strategis dan berpotensi untuk menarik minat para pelanggan. Maka dari itu kenapa capcin Abude ini masih bisa bertahan hingga saat ini yaitu karena mereka bisa tetap mempertahankan rasa, kualitas dan harga. Sehingg jika sudah demikian usaha tersebut kemungkinan besar akan bertahan lama.

Brend Abude sendiri juga banyak diminati oleh para wirausahawan lainnya, namun mereka menjual Brend pada saat ini hanya untuk orang yang berada di luar kota dan juga belum ada cabang capcin Abude di daerah tersebut. Harga penjualan Brand itu sendiri mencapai Rp. 30.000.000, dari harga tersebut sudah mencakup di dalamnya gerobak dan bahan baku dari es cappucino ini.

Cabang utama capcin Abude yang di pegang oleh Budi Permana sendiri terletak di Jl. Cempaka IX, Mawar, Kec. Banjarmasin Tengah, Kota Banjarmasin, Kalimantan Selatan. Selain itu ada 20 cabang capcin Abude yang berjalan atas kerjasama dengan orang lain, yaitu di Banjarmasin ada 12 cabang, Handil Bakti 2 cabang, Pelaihari 3 cabang, Banjarbaru 1 cabang, Martupara 1 cabang, dan Barabai 1 cabang. Hasil penjualan yang dimiliki oleh setiap cabang tidak dibagaikan dengan Budi Permana melainkan hanya untuk masing-masing pengelola disetiap cabang tersebut. Budi Permana hanya menjadi pemasok bahan baku untuk capcinnnya saja, dari sanalah ia juga akan mendapatkan keuntungan. Meskipun ia pada dasarnya tidak mengikat pengelola tiap cabang untuk membeli bahan baku dari dia, tapi karena harga dan 
kualitas bahan baku yang ia miliki lebih baik maka akan secara otomatis para pengelola tiap cabang akan membeli bahan baku ditempatnya.

Pada awal pertama jualan yaitu di Jl. Cempaka, capcin yang laku pada hari pertama jualan yaitu hanya 2 porsi dan ternyata hari-hari berikutnya masih sama seperti demikian tidak ada peningkatkan hingga berjalan 1 minggu. Akhirnya Budi Permana dan tim memutuskan untuk menutup usaha ini dan melakukan evaluasi selama 3 bulan. Beliau berdiskusi bersama tim mencari terkait dengan masalah usaha yang mereka hadapi. Setelah melakukan diskusi yang panjang tersebut akhirnya mereka menemukan ide baru terkait dengan strategi promosi. Beliau kemudian memutuskan untuk membuka usaha capcin kembali di tempat yang sama.

Pada hari pertama buka kembali Budi Permana bersama tim langsung merealisasikan strategi promosi mereka dengan membagikan es cappucino cincau secara gratis kepada orangorang yang lewat di depan outlet mereka. Sebenarnya jika kita pikir menggunakan logika promosi seperti itu justru akan mengakibatkan kerugian besar, tetapi hal tersebut tetap mereka lakukan. Bahkan promosi tersebut tidak hanya berlangsung selama1 hari, tetapi berlangsung selama 3 hari. Sehingga kerugian yang mereka alami mencapai Rp. 2000.000,. Namun setelah dilakukannya strategi promosi tersebut ternyata ada peningkatan, hari keempatnya penjualan meningkat menjadi 50 porsi. Dapat dibandingkan dengan sebelum dilakukannya strategi promosi tersebut capcin hanya terjual 2 sampai 3 porsi perharinya. Hari-hari berikutnya penjualan semakin meningkat hingga ratusan gelas perharinya bahkan sampai sekarang mencapai seribu gelas perharinya. Strategi promosi seperti itu akhirnya dipakai untuk beberapa cabang yang baru buka meskipun promosinya tidak seekstrem yang dulu. Kemudian setelah pendapatan mulai meningkat Budi Permana kemudian menambahkan menu pendamping pentol bakar, martabak mini dan berbagai macam gorengan lainnya. Sehingga pendapatan seribu gelas perhari selalu stabil terjadi hingga sekarang di outlet beliau yang ada di cempaka.

Pada era globalisasi saat ini kemajuan IPTEK sangat berkembang dengan pesat begitu pula halnya dalam dunia pendidikan dalam Abad-21, dengan proses pembelajaran yang memanfaatkan seluruh kemajuan teknologi untuk menunjang proses pembelajaran efektif. (Mutiani, M., \& Faisal, M, 2019). Memasuki era globalisasi dunia yang semakin transparan tidak dapat dipungkiri bahwa nantinya calon generasi bangsa juga ketat bersaing dalam dunia usaha, jika tidak dipersiapkan dari sekarang maka mereka akan tertinggal dan tidak mampu bersaing dalam dunia usaha. 
Persaingan bisnis selalu terjadi baik dalam ranah nasional maupun internasional, maka itu sejak masih sekolah diajarkan untuk bisa menemukan ide usaha yang kreatif dan inovastif sehingga ia nantinya bisa bersaing dalam dunia usaha. Negara memerlukan generasi yang mampu ikut andil bersaing dalam memajukan bangsanya dalam perdagangan internasional. Peran para wirausahawan disini sangat diperlukan untuk memberikan sumbangsih besar bagi kemajuan bangsa. (Hasanah, M, 2020).

Pemanfaatan usaha Capcin ini bisa dikaitkan dalam pembelajaran IPS dan dapat dijadikan sumber belajar IPS, yang dimana pembelajaran IPS ini terintegrasi dari berbagai disiplin ilmu. Salah satunya yaitu ilmu ekonomi. Dalam usaha ini kita bisa memanamkan kepada peserta didik nilai keterampilan dan sikap dalam menjalankan suatu usaha atau kegiatan ekonomi. (Jumriani, J, 2018). Karena IPS sendiri bertujuan untuk menjadikan warga negara yang baik yang dapat memiliki kemampuan dalam afektif kognitif dan psikomotoriknya. Sehingga dari sana akan terciptalah pembelajaraan IPS yang berkualitas dengan mengaitkan berbagai kegiatan yang berada dilingkungan sekitar para peserta didik. (Wahyuningsih, S., Abbas, E. W., \& Mutiani, M, 2020).

\section{SIMPULAN}

Franchise merupakan usaha yang banyak diminati dan digeluti oleh kalangan masyarakat Indonesia. Namun untuk membangun sebuah usaha itu harus memperhatikan berbagai aspek seperti kondisi pasar, pemilihan tempat yang strategis, kualitas dan harga dari produk yang akan di pasarkan. Tentunya semua ini nantinya akan menentukan seberapa lama usaha kita akan terus bertahan.

Membangun suatu usaha itu tentunya tidak selalu berjalan mulus akan ada problema yang di hadapi kedepannya. Namun dari berbagai problema tersebut jangan sampai mematahkan semangat kita untuk terus membangun usaha yang geluti. Jangan pernah ragu dalam mengambil sebuah keputusan demi mencapai keberhasilan suatu usaha. Jadikanlah suatu kegagalan yang dialami menjadi sebuah pembelajaran, karena untuk mencapai keberhasilan kita pasti melewati berbagai rintangan pahit sebelumnya. Sehingga keberhasilan yang diperoleh nantinyapun akan memberikan nilai yang sangat berkesan baik bagi diri sendiri maupun orang yang ada di sekeliling kita.

\section{DAFTAR PUSTAKA}


ABBAS, E. W., Hidayat Putra, M. A., \& Noor Handy, M. R. (2019). Laporan Penelitian : PEMANFAATAN EKOWISATA SUNGAI MARTAPURA KOTA BANJARMASIN SEBAGAI SUMBER BELAJAR IPS.

Andini, D. P. (2013). STUDI KELAYAKAN USAHA WARALABA WARUNG "PANGESTU" DI KABUPATEN JEMBER. Jurnal Ilmiah Inovasi, 13 (2).

Firdawaty, L. (2011). Perjanjian Waralaba Menurut Hukum Islam. ASAS, 3(1).

Hasanah, M. (2020). Pendidikan Kewirausahaan

Jumriani, J. (2018). KEGIATAN PRODUKSI DAN DISTRIBUSI DI KAMPUNG SASIRANGAN SEBAGAI SUMBER BELAJAR IPS. Jurnal Socius, 7(1).

Mutiani, M., \& Faisal, M. (2019). Urgency of The 21st Century Skills and Social Capital in Social Studies. The Innovation of Social Studies Journal, 1(1), 1-11.

Pamungkas, R., \& Magnadi, R. H. (2014). Faktor-Faktor Yang Mempengaruhi Keberhasilan Usaha Pemegang Usahan Waralaba (Studi Kasus Pada Waralaba Makanan Dan Minuman Lokal Di Kota Semarang). Doctoral dissertation, Fakultan Ekonomika dan Bisnis.

Sanawiri, B., \& Iqbal, M. (2018). Kewirausahaan. Universitas Brawijaya Press.

Sunarya, P. A., \& Saefullah, A. (2011). Kewirausahaan. Penerbit Andi.

Wahyuningsih, S., Abbas, E. W., \& Mutiani, M. (2020). Implementation of Leadership Value of Rudy Resnawan as a Learning Resources on Social Studies. The Innovation of Social Studies Journal, 1(2), 169-177. 